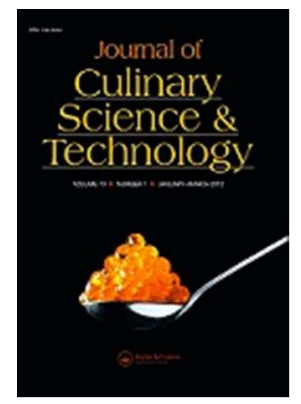

\title{
Using trendsetting chefs to design new culinary preparations with the "Penjar" tomato
}

\begin{tabular}{|r|l|}
\hline Journal: & Journal of Culinary Science \& Technology \\
\hline Manuscript ID: & Draft \\
\hline Manuscript Type: & Original \\
\hline Keywords: & $\begin{array}{l}\text { Culinary and Food Innovation, Sensory evaluation, Food product } \\
\text { development }\end{array}$ \\
\hline \multicolumn{2}{|l}{} \\
\hline
\end{tabular}

SCHOLARONE $^{\text {"x }}$
Manuscripts

URL: http://mc.manuscriptcentral.com/wcsc Email: rharring@uark.edu 


\section{Abstract}

3 New food products are normally marketed after research into consumers' preferences. As

4 an alternative, we used trendsetting chefs to develop and evaluate products with the 5 traditional long shelf life "Penjar" tomato (alc gene). The most appreciated creations 6 were Catalan bread with tomato, tomato sauce and tomato jam, excelling by its flavor 7 complexity and balance. The description of the products by a trained panel revealed 8 significant differences between varieties (especially between the food products 9 elaborated with the "Penjar" type and conventional tomatoes). However, it was not easy 10 to match the chefs' assessments about sensory properties with the panel descriptions.

\section{Highlights}

13 Trendsetting chefs prepared food elaborations using tomatoes with the alc gene. In their 14 opinions, some varieties and elaborations were promising. The elaborations were 15 submitted to scientific sensory analysis. Further studies are required to accommodate 16 trendsetting chefs' opinions to sensory analysis.

\section{Introduction}

The design of new fresh food products (fruit, vegetables, etc.) or of transformed food products (dairy products, prepared dishes, canned foods, etc.) is normally preceded by a

\section{Keywords}

Trendsetting chefs, alc gene, sensory analysis, tomato, jam, Catalan bread with tomato, tomato soup, tomato sauce, sensory preferences

28 1998). If a product seems promising, it is usually tested by a panel trained to describe its

29 main attributes. This approach makes it possible to work with objective sensory traits

30 and scales to improve both the raw material and the processes of transformation.

31 This strategy requires well-planned surveys and a good sample universe, making it 
32 economically unfeasible for all except large companies. Thus, many local raw materials

33 that are highly appreciated when consumed fresh are not transformed into new

$34 \quad$ competitive products.

35 Global communications media have helped create trendsetting references for all 36 consumer products, from clothing to wine (Gaiter and Brecher, 2002; Johnson and 37 Robinson, 2006; Parker, 2008) to cuisine (Michelin Travel and Lifestyle, 2010). These 38 trendsetters create new alternatives that often find a place in the market through 39 their creators' special talent at guessing what consumers will like. This approach to 40 finding new uses for the wealth of traditional raw materials found in many places around 41 the world has received little attention.

42 The Alícia Foundation, whose name is derived from combining the Catalan words for 43 alimentation and science, works to design new preparations to make everyday food both 44 tasty and healthy. Under the direction of the prestigious chef Ferran Adrià, chefs and 45 researchers (food technologists, chemists, nutritionists, etc.) work together at Alícia to 46 elaborate and evaluate new dishes based on tradition and culinary research.

47 The Miquel Agustí Foundation (MAF), linked to BarcelonaTech (UPC), is an 48 organization in which farmers, plant breeders, chemists, and food technologists 49 experienced in sensory analysis work together to recover traditional varieties that are 50 appreciated for their sensory value so they can be used directly or in elaborated products.

51 One product being recovered is the "Penjar" tomato, which has an average shelf life of 52 more than 6 months (thanks to the alc gene) (Casals et al., 2011b). The "Penjar" type of 53 tomato ("Penjar" means "for hanging" in Catalan) is thus named because the fruits are 54 hung from the rafters under the roofs of farmhouses after harvesting. This type 55 comprises a set of varieties with wide variation in agricultural characteristics, 
56 morphological traits, and genetic background. Furthermore, some of these varieties have,

57 in different intensities, a characteristic flavor described as "sharp with floral notes". This

58 flavor increases during the first two months after harvesting and reaches its maximum

59 intensity two to four months after harvesting (Casals et al., 2011a; Casals et al., 2011c).

60 The intensity and type of flavors after harvesting depend on the genetic background but

61 do not seem to be related with the alc gene. In fact, tomatoes having long shelf life

62 genes different than alc are generally considered to lack flavor (Baldwin et al., 2000;

63 Kopeliovitch et al., 1982; Kovacs et al., 2009; McGlasson et al., 1987). "Penjar"

64 tomatoes are used mainly in the Mediterranean regions of Spain (the Balearic Islands,

65 Catalonia, and Valencia) as well as in some regions of Italy. In Catalonia they are

66 especially appreciated for preparing traditional "bread with tomato". "Penjar" tomatoes

67 are especially suitable for this dish because nearly all the tomato is transferred to the

68 bread when they are rubbed on. Traditionally, the "Penjar" tomato has made it possible

69 to have "fresh" tomatoes in cold seasons when it is impossible to cultivate them.

70 During the research to recover this tomato, we considered that the special flavor found

71 in some varieties might be used for purposes other than "bread with tomato". The

72 availability of food products derived from the "Penjar" tomato would make it possible

73 to reach a wider market, and the availability of canned or otherwise preserved "Penjar"

74 tomatoes would expand the period of sales beyond the current limitations (November

75 through April) to encompass the entire year.

76 Because "Penjar" tomatoes are grown on small farms, individual farmers do not have

77 the means to carry out market studies and design transformed products. For this reason,

78 the Alícia Foundation and the MAF jointly proposed to: i) have chefs develop and

79 evaluate culinary preparations from diverse "Penjar" tomatoes, and ii) carry out a

80 scientific sensory analysis of the chefs' creations and relate it to chefs' preferences so 
81 the relevant traits can be included in breeding programs of the "Penjar" tomato type.

82

83

84

85

86

87

88

89

90

91

92

93

94

95

96

97

98

99

100

101

102

103

\section{Material and methods}

\subsection{Plant material}

Five varieties of tomato were used in the trial, including four varieties of "Penjar" tomato (containing the alc gene) selected by the MAF and one commercial variety in which the alc gene was not present:

a) Punxa $(a l c)$. This variety has a pronounced nipplelike protrusion at the base of the fruit. Fruits are spherical, with a diameter of about $50 \mathrm{~mm}$ and average weight of $60 \mathrm{~g}$. The mean yield per plant is $2634 \mathrm{~g}$. This variety has very long shelf life; $91 \%$ of the fruit remain suitable for consumption two months after harvesting and $85 \%$ remain suitable for consumption after four months. The intensity of the flavor two to four months after harvesting is high, with earthy flavors mixed with tangy and sweet flavors.

b) LC215 (alc). This variety has large, rounded though slightly flattened fruits, measuring $60 \mathrm{~mm}$ in width and $53 \mathrm{~mm}$ in height and weighing on average $100 \mathrm{~g}$. The mean yield per plant is $2344 \mathrm{~g}$. Approximately $70 \%$ of the fruits remain suitable for consumption two months after harvesting and $47 \%$ remain suitable four months after harvesting. The intensity of the flavor two to four months after harvesting is medium and dominated by earthy tones.

c) LC209 (alc). This variety has fruits ranging from flattened to rounded, measuring 61 $\mathrm{mm}$ in width and $46 \mathrm{~mm}$ in height and weighing on average $78 \mathrm{~g}$. The mean yield per plant is $3453 \mathrm{~g}$. Approximately $63 \%$ of the fruits remain suitable for consumption two months after harvesting and $51 \%$ remain suitable after four months. Like the variety 
104 LC215, the intensity of the flavor two to four months after harvesting is medium and 105 dominated by earthy tones.

106 d) LC401 (alc). This variety has considerably flattened fruits, measuring $64 \mathrm{~mm}$ in 107 width and $47 \mathrm{~mm}$ in height and weighing on average $82 \mathrm{~g}$. The mean yield per plant is 1082950 g. Approximately $72 \%$ of the fruits remain suitable for consumption two months 109 after harvesting and 53\% remain suitable after four months. The intensity of the flavor 110 two to four months after harvesting is medium and dominated by earthy tones.

111 e) Canary. Commercial variety of tomato chosen as representative of tomatoes with 112 long shelf life that is not conferred by the alc gene and that do not develop new flavors 113 after harvesting; these tomatoes have very firm flesh and this makes them unsuitable for 114 "bread with tomato". The fruits are rounded and large (96 g on average), the shelf life is 115 short (less than one month), and flavors do not enhance after harvesting.

\subsection{Cultivation of tomatoes for the trials}

118 The "Penjar" tomatoes were cultivated in Vallès Occidental County in northeast Spain 119 in alkaline loamy clay. Seedlings were transplanted May 15 and fruits were harvested in 120 the red ripe stage in August. Plants received drip irrigation, fertilizer, and treatments as 121 necessary to ensure they did not suffer any kind of stress. After harvesting, the fruits 122 were stored in darkness at $20 \pm 5^{\circ} \mathrm{C}$ and $65 \%$ to $75 \%$ relative humidity for four months 123 before culinary transformation and sensory evaluation.

The Canary variety, with a limited long shelf life, was cultivated in greenhouses and 125 was harvested in the red ripe stage shortly before the culinary trials. 
127

128

129

130

131

132

133

134

135

136

137

\subsection{Culinary preparations}

The team of chefs at the Alícia Founation decided to elaborate the culinary preparations taking care not to mask the characteristics of the raw material and applying their experience to highlight the particular characteristics that might interest consumers. Thus, the amount of accompanying substances (salt, oil, vinegar, sugar) was limited. The preparation "bread with tomato" was used to compare the tomatoes for their habitual use, without transformation. A cold tomato soup, tomato sauce, and tomato jam were proposed as candidates for preparations that might interest consumers. Various preliminary trials were carried out using commercial and experimental tomatoes to refine the different recipes until they were considered appropriate for the trial. All assessments of each preparation were done simultaneously with the same working conditions, time, and temperature for each replication.

\subsection{Chefs' evaluation}

Six chefs/researchers from the Alícia Foundation, including the ones who had prepared the different dishes with the tomatoes, gave their opinion about the presumable acceptability of the preparations to consumers. The chefs had varied ages, cultural backgrounds, and culinary trends. So, we consider their combined opinion a suitable reference about the degree of acceptability that these tomatoes might have in the market beyond their traditional use for making "bread with tomato".

The chefs openly discussed each preparation according to their usual method of working until they reached a consensus about the product's potential value. At the same time, they noted down the points and arguments in favor and against each preparation and each variety of tomato. 


\subsection{Sensory analysis}

153 A panel of 10 judges with prior experience in the sensory analysis of tomatoes (Casals 154 et al., 2011c) and of dried beans (Romero del Castillo et al., 2008) was specifically 155 trained to evaluate different culinary preparations elaborated with a wide range of 156 commercial and experimental tomatoes. This enabled the panel to choose the attributes 157 that best characterized each product and to fix the extremes of the scales.

158 A semi-structured scale ranging from 0 to 10 (Meilgaard et al., 1999) was constructed 159 for each of the attributes selected for the following products:

"Bread with tomato": color $(0=$ orangish-yellow, $10=$ maroon-red $)$, sweetness, acidity, 161 and intensity of flavor.

162 "Cold tomato soup": color, sweetness, acidity, consistency ( $0=$ liquid, $10=$ very dense), 163 fibrosity $(0=$ no perceptible fibers, $10=$ many perceptible fibers and remains of pulp 164 and/or skin), and intensity of tomato flavor.

165 "Tomato jam": color, consistency ( $0=$ liquid, 10= very jellied), sweetness, acidity, 166 intensity of aroma, intensity of flavor.

167 "Tomato sauce": color, consistency $(0=$ separation of liquid and solid, $10=$ consistent 168 sauce), sweetness, acidity, and intensity of flavor.

169 Given that the chefs often used the word "balance" in their descriptions, we created an 170 attribute named "balance" (which does not necessarily correspond to the same concept 171 that the chefs referred to; it is likely that the chefs' meaning includes more aspects than 172 those strictly defined here), calculated as (sweetness - acidity)/(sweetness + acidity). 173 The values of this attribute range from -1 to 1 . Zero represents maximum balance, 
174 values near -1 represent a high predominance of acidity, and those near 1 represent a 175 high predominance of sweetness.

176 To evaluate the preparation "bread with tomato", one slice of bread $(10 \mathrm{~cm} \times 5 \mathrm{~cm} \times 0.8$ $177 \mathrm{~cm})$ was presented for each tomato evaluated. To evaluate the "cold tomato soup" 178 preparations, $50 \mathrm{ml}$ was presented in a glass. To evaluate the "tomato sauce" and 179 "tomato jam" preparations, $30 \mathrm{~g}$ of each sample were presented in individual bowls. All 180 samples were presented at room temperature $\left(20^{\circ} \mathrm{C}\right)$ and identified with three randomly 181 assigned digits. eight independent sessions; in each session, the panel evaluated the same preparation made from each of the five varieties of tomato (four different preparations $\times 2$ sessions 187 for each $=8$ sessions).

The tasting sessions took place in a room that was specially designed for sensory analysis (ISO International Standard 8589, 2007). To evaluate all the attributes except color in each preparation, the tasting cabins were illuminated with green light to mask the color of the samples and thus avoid the influence of visual impressions.

We used the linear model $x_{\mathrm{ijk}}=\mu+\mathrm{v}_{\mathrm{i}}+\mathrm{p}_{\mathrm{j}}+\mathrm{s}_{\mathrm{k}}+\mathrm{vp}_{\mathrm{ij}}+\varepsilon_{\mathrm{ijk}}$ to calculate the effects for variety (v), panelist (p), session (s), and the interaction variety x panelist. Factors with an $\mathrm{F}$ value with $\mathrm{p} \leq 0.05$ were considered significant.

195 To make it possible to graphically compare the sensory attributes (range 0 to 10) with 196 the attribute balance (range -1 to 1 ), each of the attributes was normalized by subtracting 197 the mean of each attribute and dividing it by its standard deviation: $x_{N}=\left(x_{i}-x\right) / S D(x)$, 

$\mathrm{x}_{\mathrm{N}}=\left(\mathrm{x}_{\mathrm{i}}-\mathrm{x}\right) / \mathrm{SD}(\mathrm{x})$. This transformation resulted in attributes centered on zero and with a standard deviation of 1 ; thus, values greater than 2 or less than -2 denote an atypical value for the attribute.

The data were processed using the SAS statistical package (SAS Institute Inc., 1999).

\section{Results}

\subsection{Culinary preparations}

Bread with tomato: a) Ingredients: Bread (sliced cottage loaf, baked the previous day to provide a more compact structure for the product), tomato, salt, and refined olive oil (maximum acidity $0.3 \mathrm{o}$ ) to avoid masking the flavor of the tomato with intensive olive oil flavor. b) Procedure: Wash the tomatoes, slice them in half transversely, and rub them over the slice of bread immediately before serving. Sprinkle salt (approximately $0.3 \mathrm{~g}$ ) and dribble olive oil (approximately $5 \mathrm{~g}$ ) over the tomato.

Cold tomato soup: a) Ingredients: $500 \mathrm{~g}$ tomatoes, $100 \mathrm{~g}$ mineral water, $3 \mathrm{~g}$ salt, $50 \mathrm{~g}$ refined olive oil (maximum acidity $0.3^{\circ}$ ), $5 \mathrm{~g}$ balsamic vinegar. b) Procedure: Wash the tomatoes and remove the peduncle. Cut them into chunks, place them in a container with the water, and triturate them with an immersion blender. Strain the blend of triturated tomatoes and water through a China cap. Season with salt, dress with the oil and vinegar, and emulsify with the immersion blender. Serve immediately (before the emulsion loses its homogeneity).

Tomato sauce: a) Ingredients: $1250 \mathrm{~g}$ grated tomato, $100 \mathrm{~g}$ olive oil, $10 \mathrm{~g}$ salt. b) Procedure: Place the oil and grated tomatoes in a saucepan, add the salt, and sauté over a low flame for at least 2 hours until the mixture is reduced. Stir continually. 
221 Tomato jam: a) Ingredients: Tomatoes, sugar $(50 \%$ of the weight of the prepared 222 tomatoes $=$ after washing, peeling, and removing the seeds), Golden delicious apples (200 223 g prepared apples $=$ cored and sliced, per $1 \mathrm{~kg}$ of prepared tomatoes), fresh lemon juice 224 (20 g per $1 \mathrm{~kg}$ of prepared tomatoes). b) Procedure: Wash, scald (to facilitate the removal 225 of the skin), and peel the tomatoes. Cut the tomatoes into pieces, add the sugar and the 226 apple, and cook over a low flame. Stir well to prevent sticking and add the lemon juice. 227 Stir until the desired consistency is achieved. Traditionally, to know when the concoction 228 is ready, a few drops are dripped onto the center of a plate: if these do not slide 229 down when the plate is tilted, the jam is ready.

\subsection{Evaluation by the Fundació Alícia's chefs}

232 Bread with tomato: The chefs all agreed that the "Penjar" tomatoes were much more 233 suitable for rubbing on the bread than the Canary tomato (Table 1). As expected, it was 234 very difficult to get the flesh of the Canary tomato off the skin to adhere to the bread. 235 There was no consensus about the superiority of the flavors that developed in the 236 "Penjar" tomatoes versus those of the fresh Canary tomatoes or about the best color 237 (Table 1).

238 Cold tomato soups: In general, all the concoctions have very mild tomato flavor. Those 239 made with "Penjar" tomatoes have particular flavors (mainly earthy tones) that do not 240 give the sensation of freshness that would be expected in a cold soup (Table 2). The 241 concoction made with fresh Canary tomatoes was recognized as clearly different, 242 although it was considered to lack special gastronomic potential (Table 2).

243 Tomato sauce: The tomato sauces elaborated with "Penjar" tomatoes were considered 244 better than the one elaborated with fresh tomato (Table 3). The consistency of the sauce, 
245 the balance between acidity and sweetness, and the presence of complex flavors were

246 considered positive, although one chef preferred the fresh flavors (Table 3).

247 Tomato jams: Jams made with "Penjar" tomatoes were considered more aromatically 248 complex and better than the one made with the fresh tomato (Table 4).

\subsection{Results of the sensory analysis by the panel}

251 Bread with tomato: The variety effect was significant for color and flavor (Table 5).

252 There were four groups of significance for color. LC209 was the reddest and LC401 was

253 the lightest (Table 5). The most intense flavor was found in LC401, Punxa, and LC209.

254 Canary had the least intense flavor (Table 5).

255 Cold tomato soup: The variety effect was significant for all traits (Table 6). The soup 256 with the reddest color was made from LC209 and the soup made from LC215 was the 257 least red (Table 6). The group of most acidic varieties included Punxa, LC215, and 258 LC401. The variety LC209 was sweeter than the rest; no significant differences in 259 sweetness were observed among the other varieties. As for the texture, the consistency 260 of LC215, LC209, and Canary was thicker while Punxa and LC401 were runnier. The 261 fibrosity of LC215 was greater than that of the other varieties, among which no 262 significant differences were found (Table 6). The varieties LC215 and LC209 had the 263 most intense flavor (Table 6).

264 Tomato sauce: The variety effect was significant for all the sensory attributes except 265 flavor (Table 7). The tomato sauces made with LC209 and LC401 had the most intense 266 red color while the sauce made from LC215 had the least intense red color (Table 7). 267 The consistency of the all the sauces was greater than 5, and good cohesion between the 268 liquid and solid parts was observed in all. Sauces from the varieties LC209 and Punxa had 
269 the thickest consistency, and those of LC215 and Canary were the less consistent (more 270 watery) (Table 7). Acidity was highest in sauces made with Canary, followed by Punxa 271 (Table 7). Sweetness was highest in LC401 sauce and lowest in the Canary sauce (Table $2727)$.

273 Tomato jam: The variety effect was significant for all attributes except consistency and 274 sweetness (Table 8). The intensity of the red color was highest in jams made from LC209 275 and LC401 (Table 8). The jams made with the "Penjar" varieties were more consistent 276 (thicker) than the jam made with the fresh variety (Table 8). Acidity was highest in jams 277 made from Punxa or Canary and lowest in LC215. Jams made from LC215 or LC401 278 were considered the most aromatic (Table 8).

\section{Discussion}

\subsection{The culinary preparations}

Bread with tomato: As expected, the "Penjar" tomato had a much better transfer when spread over the bread. One group of chefs preferred bread with tomato made with fresh tomatoes and another preferred bread with tomato made with "Penjar" tomatoes.

286 with their cultural backgrounds. The panel's sensory analysis pointed out that "Penjar" 287 tomatoes have a more intense flavor than the fresh tomato and wide variation in color. 288 The panel found no differences in acidity or sweetness, probably because these attributes 289 are difficult to appreciate when they are combined with the characteristics of the oil and 290 bread (Tables 5 and 9). It would make sense to increase the complex flavor (earthy and 291 sharp) of these tomatoes as many of the chefs appreciated this characteristic. Another line 292 of research would be to increase the spreading abilities of tomatoes with intense fresh 
293 flavor that do not have the alc gene to please another segment of the market.

294 Cold tomato soup: None of the cold tomato soups was considered especially interesting

295 by the chefs (Table 2). Those made from "Penjar" tomatoes were considered to have 296 excessively complex flavors and the one made from fresh conventional tomatoes was 297 considered to lack consistency and flavor intensity. The sensory analysis showed there are 298 major differences between varieties of "Penjar" tomatoes when each trait is evaluated 299 individually (Table 6). However, according to the chefs, all the "Penjar" varieties have 300 significant shortcomings that must be overcome if they are to be used for this purpose 301 (Table 2). The results suggest that it would be better to make cold tomato soups from 302 more flavorful fresh tomatoes.

303 Tomato sauce: The chefs' cited the consistency, balance between acidity and 304 sweetness, and presence of complex flavors as the most desirable characteristics in this 305 preparation, although two of them considered that a flavor of freshness was more 306 desirable than complex flavors. Punxa and LC215 were considered to best fulfill these 307 criteria. In the sensory analysis (Table 7), Punxa was in the highest group of 308 significance for consistency but LC215 was not. These two varieties also belong to 309 different groups of significance for the balance between acidity and sweetness (Table 7). 310 So, the chefs' concepts of consistency and acid-sweet balance probably do not 311 correspond to those the panelists were trained in.

312 The chefs considered the "complexity of flavors" to be the most positive characteristic 313 of the tomato sauce. In future studies, the panel should be trained to discriminate the 314 intensities of different flavors (earthy, sharp, and others) like chefs do, and breeding 315 programs should select for these traits. Moreover, the chefs' concept of balance should 316 be deeply analyzed to translate it into panel measurements useful for breeding programs. 
317 Tomato jam: The chefs also considered the jams made from "Penjar" tomatoes to be 318 superior, fundamentally because they had more complex flavors. The varieties LC401 319 (predominance of acidity over sweetness), LC215, and Punxa (both with good balance 320 between acidity and sweetness) were considered the best because of the intensity of 321 their complex flavors.

322 Again, the terms the chefs used to justify their preferences were the same as those used 323 by the panel but the concepts represented by these terms do not coincide. Although the 324 chefs considered Punxa and LC215 to be balanced and both varieties belong to the same 325 group of significance for this trait (Table 8), the panel considered the jams made from 326 these varieties to be predominantly sweet (values around 0.5 ).

\subsection{The varieties}

The chefs always recognized differences between "Penjar" tomatoes and fresh tomatoes, pointing out the value of "Penjar" tomatoes in "bread with tomato" 331 preparations (spreading capacity, together with the flavor of fresh tomatoes or with 332 complex flavors, depending on the group of chefs), in tomato sauce preparations 333 (consistency, balance between acidity and sweetness, complex flavor), and in tomato 334 jam (balance between acidity and sweetness, complex flavor).

335 The panel approach found differences between the fresh tomato and "Penjar tomatoes", 336 but, in general, the differences between the varieties of "Penjar" tomatoes that the chefs 337 pointed out to justify their opinions about the products do not correspond with the 338 differences that the panel detected (Tables 5, 6, 7, 8 and Figure 1). 
340

341

342

343

344

345

346

\subsection{The trendsetting chefs' evaluations versus the sensory panel's descriptions}

Sensory analysis by a trained panel was not especially successful at identifying welldefined traits that could be related to the chefs' preferences and subsequently used for selection in breeding programs. It seems that the chefs consider a culinary creation as a whole (they make their choices by considering all the aspects together rather than by analyzing them individually). Although chefs sometimes talk about attributes, they do so without having reached a previous consensus about the definition of these attributes, and this contrasts sharply with the panelists' use of attributes for analysis. The chefs have a clear idea about what they like, but they are unaccustomed to formal analysis and defining descriptors to explain why they prefer one option over another.

To accommodate the two approaches, it is essential to translate the chefs' language to the panelists' language. One way to accomplish this would be to train the chefs in the attributes and scales that the panelists use to describe the characteristics of the product; in this case, the two groups would share a common language and the problem would disappear. However, we are not convinced that this is the best way, because the chefs' work requires impressions derived more from synthesis than from analysis.

\subsection{Conclusions}

According to the chefs' proposals and evaluations some "Penjar" tomatoes are an excellent source for tomato sauce and tomato jam, going beyond its traditional "bread with tomato" use.

Probably some consumers will not like dishes prepared with "Penjar" tomatoes as two of the chefs preferred the flavor of fresh tomatoes, even though the fresh tomatoes used 
363 were not especially flavorful. According to the other four chefs, some consumers will be 364 able to appreciate the complex flavor, the balance between acidity and sweetness, and 365 the color contributed by "Penjar" tomatoes.

366 Although the most relevant attributes for the chefs (intensity of color, consistency of

367 texture, intensity and complexity of flavor, low acidity in sauces, and high sweetness in 368 jam) are fairly general in the four varieties of "Penjar", there are differences between 369 varieties that make some better than others for each preparation. Nevertheless, Punxa 370 seems to be the best overall variety.

371 In a short time and with little funding, our combined approach led to various creations 372 that can help increase the consumption of a peculiar raw material. This is especially 373 important, considering that the business around prestigious landraces is not controlled 374 by large companies that can afford to invest in market studies. However, the difficulties 375 of combining the two approaches are also evident. The chefs' explanations of their 376 preferences often were difficult to match with the panel's analytical assessment. 377 Although the two groups often used the same terms, it seems they were not referring to 378 the same concepts. Breeding vegetables for culinary preparations requires the clear 379 identification of the traits to be improved. So, if we can take advantage of trendsetting 380 chefs' abilities, additional work is necessary to analyze and translate their integrated 381 preferences.

\section{Acknowledgments}

384 We thank the researchers at the Alícia Foundation and at the Miquel Agustí Foundation 385 for their support throughout the study. 


\section{References}

Baldwin, E. A., Scott, J. W., Shewmaker, C. K., \& Schuch, W. (2000). Flavor trivia and tomato aroma: Biochemistry and possible mechanisms for control of important aroma components. Hortscience, 35(6), 1013-1022.

392

Casals, J., Cebolla-Cornejo, J., Roselló, S., Beltrán, J., Casañas, F., \& Nuez, F. (2011).

393

Long-term postharvest aroma evolution of tomatoes with the Alcobaça (alc)

394 mutation. European Food Research and Technology. 23, 331-342

Casals, J., Pascual, L., Cañizares, J., Cebolla-Cornejo, J., Casañas, F., \& Nuez, F. 396 (2012). Genetic basis of long shelf life and variability into Penjar tomato. Genetic Resources and Crop Evolution. 59 (2), 219-229

Casals, J., Pascual, L., Cañizares, J., Cebolla-Cornejo, J., Casañas, F., \& Nuez, F. (2011). The risks of success in quality vegetable markets: Possible genetic erosion in Marmande tomatoes (Solanum lycopersicum L.) and consumer dissatisfaction. Scientia Horticulturae. 130 (1), 78-84

Gaiter, D. J., \& Brecher, J. (2002). The Wall Street Journal Guide to Wine: New and Improved: How to Buy, Drink, and Enjoy Wine. New York: Broadway; 2 edition.

ISO International Standard 8589. (2007). Sensory analysis - General guidance for the design of test rooms. In Ref. No. ISO 8589. Geneva, Switzerland International Organization for Standardization. Johnson, H. (2011). Hugh Johnson's Pocket Wine Book 2011: Mitchell Beazley. Kopeliovitch, E., Mizrahi, Y., Rabinowitch, H. D., \& Kedar, N. (1982). Effect of the fruit-ripening mutant-genes rin and nor on the flavor of tomato fruit. Journal of the American Society for Horticultural Science, 107(3), 361-364. Kovacs, K., Fray, R. G., Tikunov, Y., Graham, N., Bradley, G., Seymour, G. B., et al. (2009). Effect of tomato pleiotropic ripening mutations on flavour volatile biosynthesis. Phytochemistry, 70 (8), 1003-1008.

Lawless, H. T., \& Heyman, H. (1998). Sensory Evaluation of Food. New York: Chapman \& Hall.

McGlasson, W. B., Last, J. H., Shaw, K. J., \& Meldrum, S. K. (1987). Influence of the non-ripening mutants rin and nor on the aroma of tomato fruit. Hortscience, 22(4), 632-634.

Meilgaard, M., Civille, G. V., \& Carr, B. T. (1999). Mesuring responses. In Sensory evaluation techniques. New York: CRC Press.

Michelin Travel \& Lifestyle. (2010). Michelin Guide Main Cities of Europe 20112011 : 
422 Hotels \& Restaurants: Michelin Editions des Voyages; 30 edition.

423 Parker, R. M. (2008). Parker's Wine Buyer's Guide, 7th Edition: The Complete, Easy-

424 to-Use Reference on Recent Vintages, Prices, and Ratings for more than 8,000 Wines

425 from All the Major Wine Regions: Simon \& Schuster; 7 edition

426 Romero del Castillo, R., Valero, J., Casanas, F., \& Costell, E. (2008). Training, validation

427 and maintenance of a panel to evaluate the texture of dry beans (Phaseolus vulgaris L.).

428 Journal of Sensory Studies, 23(3), 303-319.

429 SAS Institute Inc. (1999). SAS/STAT® User's Guide, Version 8. In: SAS Institute Inc.

430 Cary, NC. 
Table 1. Synthesis of the Alícia's Foundation chefs' assessments of the "bread with tomato" preparations made with the different varieties of tomatoes.

\begin{tabular}{|c|c|c|c|c|c|}
\hline & Punxa & LC401 & LC209 & $\mathrm{LC215}$ & Canary \\
\hline $\begin{array}{l}\text { Suitability } \\
\text { for } \\
\text { spreading }\end{array}$ & High & High & High & High & Low \\
\hline $\begin{array}{l}\text { Color of the } \\
\text { "bread with } \\
\text { tomato" }\end{array}$ & Red & $\begin{array}{l}\text { Orangish- } \\
\text { yellow }\end{array}$ & Yellowish & Dull red & Intense red \\
\hline Balance & Good & $\begin{array}{c}\text { Acidity } \\
\text { predominant } \\
\text { over sweetness }\end{array}$ & $\begin{array}{c}\text { Acidity } \\
\text { slightly } \\
\text { greater than } \\
\text { sweetness }\end{array}$ & $\begin{array}{l}\text { Good, but } \\
\text { low acidity } \\
\text { and } \\
\text { sweetness }\end{array}$ & $\begin{array}{c}\text { Acidity } \\
\text { predominant } \\
\text { over } \\
\text { sweetness }\end{array}$ \\
\hline Flavor & $\begin{array}{c}\text { Intense, } \\
\text { different } \\
\text { from fresh } \\
\text { tomato. } \\
\text { Noteworthy } \\
\text { for } \\
\text { sweetness, } \\
\text { acidity, and } \\
\text { color. }\end{array}$ & $\begin{array}{l}\text { Mild and } \\
\text { earthy, } \\
\text { different from } \\
\text { fresh tomato }\end{array}$ & Low & $\begin{array}{l}\text { Low, but } \\
\text { different } \\
\text { from fresh } \\
\text { tomato }\end{array}$ & $\begin{array}{c}\text { Weak, of fresh } \\
\text { tomato }\end{array}$ \\
\hline $\begin{array}{l}\text { Comments } \\
\text { and } \\
\text { assessment }\end{array}$ & $\begin{array}{c}\text { Lack of } \\
\text { consensus } \\
\text { about flavors } \\
\text { different } \\
\text { from fresh } \\
\text { tomatoes }\end{array}$ & $\begin{array}{l}\text { Unappealing } \\
\text { color, too } \\
\text { many seeds, } \\
\text { lack of } \\
\text { consensus } \\
\text { about flavors } \\
\text { different from } \\
\text { fresh tomatoes }\end{array}$ & $\begin{array}{l}\text { Lacks } \\
\text { strength, } \\
\text { low } \\
\text { assessment }\end{array}$ & $\begin{array}{c}\text { Very watery, } \\
\text { lacks } \\
\text { strength, low } \\
\text { assessment }\end{array}$ & $\begin{array}{l}\text { Lack of } \\
\text { consensus } \\
\text { about the } \\
\text { value of the } \\
\text { fresh tomato } \\
\text { flavor }\end{array}$ \\
\hline
\end{tabular}


Table 2. Synthesis of the Alícia's Foundation chefs' assessments of the cold tomato soup preparations made with the different varieties of tomatoes.

\begin{tabular}{|c|c|c|c|c|c|}
\hline & Punxa & LC401 & LC209 & LC215 & Canary \\
\hline Color & Intense red & Orangish & $\begin{array}{l}\text { Orangish- } \\
\text { yellow }\end{array}$ & Orangish & Pinkish \\
\hline Texture & $\begin{array}{l}\text { Smooth, fine, } \\
\text { and thick }\end{array}$ & $\begin{array}{l}\text { Fine and } \\
\text { watery }\end{array}$ & $\begin{array}{c}\text { Very } \\
\text { watery }\end{array}$ & Thick & $\begin{array}{l}\text { Thick and } \\
\text { pulpy }\end{array}$ \\
\hline Balance & $\begin{array}{c}\text { Good } \\
\text { Very acidic } \\
\text { and very } \\
\text { sweet }\end{array}$ & Very acidic & $\begin{array}{l}\text { Very } \\
\text { acidic. } \\
\text { Spicy. }\end{array}$ & Acidic & $\begin{array}{c}\text { Good. } \\
\text { High acidity } \\
\text { and sweetness. }\end{array}$ \\
\hline Flavor & $\begin{array}{l}\text { Different } \\
\text { from fresh } \\
\text { tomato. Hint } \\
\text { of ketchup. }\end{array}$ & $\begin{array}{c}\text { Strong, } \\
\text { different from } \\
\text { fresh tomato. }\end{array}$ & $\begin{array}{l}\text { Mild, } \\
\text { different } \\
\text { from fresh } \\
\text { tomato. }\end{array}$ & $\begin{array}{c}\text { Unremarkable. } \\
\text { The oil } \\
\text { component } \\
\text { predominates. }\end{array}$ & $\begin{array}{l}\text { Fresh tomato } \\
\text { but lacking } \\
\text { intensity }\end{array}$ \\
\hline $\begin{array}{l}\text { Comments } \\
\text { and } \\
\text { assessment }\end{array}$ & $\begin{array}{l}\text { Good color } \\
\text { for soup. } \\
\text { Astringent } \\
\text { aftertaste. } \\
\text { Balanced and } \\
\text { pleasant. } \\
\text { Qualified as } \\
\text { medium } \\
\text { value. }\end{array}$ & $\begin{array}{l}\text { Qualified as } \\
\text { low value }\end{array}$ & $\begin{array}{c}\text { Good } \\
\text { flavor } \\
\text { Color too } \\
\text { pale, not } \\
\text { sweet } \\
\text { enough } \\
\text { Qualified } \\
\text { as medium } \\
\text { value }\end{array}$ & $\begin{array}{c}\text { Unappealing } \\
\text { color. Mildly } \\
\text { bitter. } \\
\text { Qualified as } \\
\text { low value. }\end{array}$ & $\begin{array}{l}\text { Color too } \\
\text { pink. } \\
\text { Flavor masked } \\
\text { by the oil. } \\
\text { Qualified as } \\
\text { low value. }\end{array}$ \\
\hline
\end{tabular}


Table 3. Synthesis of the Alícia's Foundation chefs' assessments of the tomato sauce preparations made with the different varieties of tomatoes.

\begin{tabular}{|c|c|c|c|c|c|}
\hline & Punxa & LC401 & LC209 & LC215 & Canary \\
\hline Color & Intense red & Intense red & Intense red & Red & Red \\
\hline Texture & $\begin{array}{c}\text { Good } \\
\text { consistency }\end{array}$ & $\begin{array}{c}\text { Good } \\
\text { consistency }\end{array}$ & $\begin{array}{c}\text { Good } \\
\text { consistency }\end{array}$ & $\begin{array}{c}\text { Good } \\
\text { consistency }\end{array}$ & $\begin{array}{c}\text { Poor } \\
\text { consistency }\end{array}$ \\
\hline Balance & Very good & $\begin{array}{c}\text { Marked acidity } \\
\text { and low } \\
\text { sweetness }\end{array}$ & $\begin{array}{c}\text { Marked } \\
\text { acidity and } \\
\text { low } \\
\text { sweetness }\end{array}$ & Good & $\begin{array}{c}\text { High acidity } \\
\text { and low } \\
\text { sweetness }\end{array}$ \\
\hline Flavor & Complex & Complex & $\begin{array}{l}\text { Complex, } \\
\text { but mild }\end{array}$ & $\begin{array}{l}\text { Complex, } \\
\text { but mild }\end{array}$ & $\begin{array}{l}\text { Fresh tomatc } \\
\text { flavor }\end{array}$ \\
\hline $\begin{array}{l}\text { Comments } \\
\text { and } \\
\text { assessment }\end{array}$ & $\begin{array}{l}\text { Acceptable } \\
\text { color and } \\
\text { flavors } \\
\text { Qualified as } \\
\text { high value }\end{array}$ & $\begin{array}{l}\text { Unbalanced } \\
\text { Qualified as } \\
\text { medium value }\end{array}$ & $\begin{array}{c}\text { Unbalanced } \\
\text { Qualified } \\
\text { as medium } \\
\text { value }\end{array}$ & $\begin{array}{l}\text { Lacking } \\
\text { flavor } \\
\text { Qualified as } \\
\text { medium } \\
\text { value }\end{array}$ & $\begin{array}{l}\text { Unbalanced } \\
\text { One chef } \\
\text { discrepancy } \\
\text { about the } \\
\text { value of the } \\
\text { complex } \\
\text { flavors } \\
\text { Qualified as } \\
\text { low value }\end{array}$ \\
\hline
\end{tabular}


Table 4. Synthesis of the Alícia's Foundation chefs' assessments of the tomato jam preparations made with the different varieties of tomatoes.

\begin{tabular}{|c|c|c|c|c|c|}
\hline & Punxa & LC401 & LC209 & LC215 & Canary \\
\hline Color & Red & Intense red & Intense red & Red & Dull red \\
\hline Texture & Smooth & Very smooth & Smooth & Smooth & Smooth \\
\hline Balance & $\begin{array}{c}\text { Very } \\
\text { balanced }\end{array}$ & Very balanced & $\begin{array}{l}\text { Low } \\
\text { acidity }\end{array}$ & Low acidity & High acidity \\
\hline Flavor & $\begin{array}{c}\text { Toasted }+ \\
\text { complex } \\
\text { tomato } \\
\text { flavors }\end{array}$ & $\begin{array}{l}\text { Complex } \\
\text { tomato flavors }\end{array}$ & $\begin{array}{l}\text { Low } \\
\text { intensity }\end{array}$ & $\begin{array}{l}\text { Mostly } \\
\text { complex } \\
\text { tomato } \\
\text { flavors }\end{array}$ & $\begin{array}{l}\text { Candied, but } \\
\text { not identified } \\
\text { as tomato }\end{array}$ \\
\hline $\begin{array}{l}\text { Comments } \\
\text { and } \\
\text { assessment }\end{array}$ & $\begin{array}{l}\text { Acceptable } \\
\text { color and } \\
\text { texture } \\
\text { Qualified as } \\
\text { high value }\end{array}$ & $\begin{array}{c}\text { Acceptable } \\
\text { color, texture, } \\
\text { and flavor } \\
\text { Qualified as } \\
\text { high value }\end{array}$ & $\begin{array}{l}\text { Qualified } \\
\text { as medium } \\
\text { value }\end{array}$ & $\begin{array}{l}\text { Qualified as } \\
\text { medium-to- } \\
\text { high value }\end{array}$ & $\begin{array}{c}\text { Qualified as } \\
\text { low value }\end{array}$ \\
\hline
\end{tabular}


Table 5. Comparison of mean values of each variety on all the attributes in the evaluation of "bread with tomato". Values in the same column followed by the same letter are not significantly different on the Newman-Keuls test $(\mathrm{p} \leq 0.05)$.

\begin{tabular}{lccccc}
\hline Variety & Color & Acidity & Sweetness & Intensity of flavor & Balance \\
\hline Canary & $3.96 \mathrm{c}$ & $3.70 \mathrm{a}$ & $4.92 \mathrm{a}$ & $3.76 \mathrm{c}$ & $0.141 \mathrm{a}$ \\
LC209 & $6.91 \mathrm{a}$ & $4.42 \mathrm{a}$ & $4.37 \mathrm{a}$ & $5.27 \mathrm{ab}$ & $0.005 \mathrm{a}$ \\
LC215 & $5.78 \mathrm{~b}$ & $4.19 \mathrm{a}$ & $4.28 \mathrm{a}$ & $4.13 \mathrm{bc}$ & $0.012 \mathrm{a}$ \\
LC401 & $2.32 \mathrm{~d}$ & $3.86 \mathrm{a}$ & $4.13 \mathrm{a}$ & $5.35 \mathrm{a}$ & $0.033 \mathrm{a}$ \\
Punxa & $3.54 \mathrm{c}$ & $4.69 \mathrm{a}$ & $4.33 \mathrm{a}$ & $4.66 \mathrm{abc}$ & $-0.041 \mathrm{a}$ \\
\hline
\end{tabular}

URL: http://mc.manuscriptcentral.com/wcsc Email: rharring@uark.edu 
Table 6. Comparison of mean values of each variety on all the attributes in the evaluation of "cold tomato soup". Values in the same column followed by the same letter are not significantly different on the Newman-Keuls test $(\mathrm{p} \leq 0.05)$.

\begin{tabular}{lccccccc}
\hline Variety & Color & Acidity & Sweetness & Consistency & Fibrosity & $\begin{array}{c}\text { Intensity } \\
\text { of flavor }\end{array}$ & Balance \\
\hline Canary & $4.06 \mathrm{~b}$ & $4.49 \mathrm{bc}$ & $3.68 \mathrm{~b}$ & $4.15 \mathrm{ab}$ & $3.09 \mathrm{~b}$ & $3.21 \mathrm{~b}$ & $-0.10 \mathrm{~b}$ \\
LC209 & $7.34 \mathrm{a}$ & $4.34 \mathrm{c}$ & $6.11 \mathrm{a}$ & $4.69 \mathrm{a}$ & $2.39 \mathrm{~b}$ & $4.59 \mathrm{a}$ & $0.17 \mathrm{a}$ \\
LC215 & $2.58 \mathrm{~d}$ & $5.12 \mathrm{a}$ & $4.13 \mathrm{~b}$ & $5.02 \mathrm{a}$ & $5.02 \mathrm{a}$ & $5.32 \mathrm{a}$ & $-0.11 \mathrm{~b}$ \\
LC401 & $3.24 \mathrm{c}$ & $5.28 \mathrm{ab}$ & $3.91 \mathrm{~b}$ & $3.41 \mathrm{~b}$ & $2.49 \mathrm{~b}$ & $3.32 \mathrm{~b}$ & $-0.15 \mathrm{~b}$ \\
Punxa & $3.65 \mathrm{bc}$ & $5.83 \mathrm{a}$ & $3.84 \mathrm{~b}$ & $3.49 \mathrm{~b}$ & $2.41 \mathrm{~b}$ & $2.94 \mathrm{~b}$ & $-0.21 \mathrm{~b}$ \\
\hline
\end{tabular}


Table 7. Comparison of the mean values of each variety on all the attributes in the evaluation of "tomato sauce". Values in the same column followed by the same letter are not significantly different on the Newman-Keuls test $(\mathrm{p} \leq 0.05)$.

\begin{tabular}{llccccc}
\hline Variety & Color & Consistency & Acidity & Sweetness & $\begin{array}{c}\text { Intensity } \\
\text { of flavor }\end{array}$ & Balance \\
\hline Canary & $4.84 \mathrm{bc}$ & $5.63 \mathrm{c}$ & $8.39 \mathrm{a}$ & $2.29 \mathrm{~d}$ & $5.63 \mathrm{a}$ & $-0.567 \mathrm{c}$ \\
LC209 & $8.04 \mathrm{a}$ & $7.18 \mathrm{a}$ & $5.12 \mathrm{c}$ & $3.51 \mathrm{c}$ & $5.21 \mathrm{a}$ & $-0.247 \mathrm{~b}$ \\
LC215 & $4.19 \mathrm{c}$ & $5.71 \mathrm{c}$ & $4.56 \mathrm{c}$ & $4.64 \mathrm{~b}$ & $4.62 \mathrm{a}$ & $0.033 \mathrm{a}$ \\
LC401 & $7.47 \mathrm{a}$ & $6.30 \mathrm{~b}$ & $4.71 \mathrm{c}$ & $5.91 \mathrm{a}$ & $5.42 \mathrm{a}$ & $0.126 \mathrm{a}$ \\
Punxa & $5.37 \mathrm{~b}$ & $6.67 \mathrm{ab}$ & $7.27 \mathrm{~b}$ & $2.96 \mathrm{~cd}$ & $4.96 \mathrm{a}$ & $-0.452 \mathrm{c}$ \\
\hline
\end{tabular}


Table 8. Comparison of the mean values of each variety on in the evaluation of "tomato jam". Values in the same column followed by the same letter are not significantly different on the Newman-Keuls test $(\mathrm{p} \leq 0.05)$.

\begin{tabular}{llclllll}
\hline Variety & Color & Consistency & Acidity & Sweetness & $\begin{array}{l}\text { Intensity } \\
\text { of aroma }\end{array}$ & $\begin{array}{l}\text { Intensity } \\
\text { of flavor }\end{array}$ & Balance \\
\hline Canary & $4.45 \mathrm{~b}$ & $5.59 \mathrm{~b}$ & $3.25 \mathrm{a}$ & $6.88 \mathrm{~b}$ & $3.04 \mathrm{bc}$ & $2.78 \mathrm{~b}$ & $0.36 \mathrm{~b}$ \\
LC209 & $7.30 \mathrm{a}$ & $6.24 \mathrm{ab}$ & $2.29 \mathrm{bc}$ & $7.05 \mathrm{~b}$ & $3.03 \mathrm{bc}$ & $3.25 \mathrm{ab}$ & $0.51 \mathrm{ab}$ \\
LC215 & $5.07 \mathrm{~b}$ & $5.95 \mathrm{ab}$ & $1.95 \mathrm{c}$ & $7.95 \mathrm{a}$ & $3.98 \mathrm{a}$ & $3.87 \mathrm{a}$ & $0.61 \mathrm{a}$ \\
LC401 & $7.04 \mathrm{a}$ & $6.49 \mathrm{a}$ & $2.56 \mathrm{~b}$ & $6.76 \mathrm{~b}$ & $3.92 \mathrm{ab}$ & $3.83 \mathrm{a}$ & $0.45 \mathrm{ab}$ \\
Punxa & $5.15 \mathrm{~b}$ & $6.21 \mathrm{ab}$ & $3.33 \mathrm{a}$ & $7.34 \mathrm{ab}$ & $2.67 \mathrm{c}$ & $3.07 \mathrm{ab}$ & $0.38 \mathrm{ab}$ \\
\hline
\end{tabular}


Table 9. Comparison of the mean value of the Penjar varieties with the fresh variety used as a check for the different preparations and attributes.

\begin{tabular}{llcccccc}
\hline Preparation & Genotype & Color & Texture & Acidity & Sweetness & Flavor & Balance \\
\hline $\begin{array}{l}\text { Bread with } \\
\text { tomato }\end{array}$ & $\begin{array}{l}\text { Penjar mean } \\
\text { Canary }\end{array}$ & $4.63 \mathrm{a}$ &. & $4.30 \mathrm{a}$ & $4.26 \mathrm{a}$ & $4.85 \mathrm{a}$ & $-0.01 \mathrm{a}$ \\
& & $\cdot$ & $3.71 \mathrm{a}$ & $4.89 \mathrm{a}$ & $3.76 \mathrm{~b}$ & $0.14 \mathrm{a}$ \\
$\begin{array}{l}\text { Cold } \\
\text { tomato }\end{array}$ & Penjar mean & $4.19 \mathrm{a}$ & $4.15 \mathrm{a}$ & $5.14 \mathrm{a}$ & $4.50 \mathrm{a}$ & $4.04 \mathrm{a}$ & $-0.07 \mathrm{a}$ \\
soup & Canary & $4.05 \mathrm{a}$ & $4.15 \mathrm{a}$ & $4.49 \mathrm{a}$ & $3.68 \mathrm{~b}$ & $3.21 \mathrm{a}$ & $-0.10 \mathrm{a}$ \\
& & & & & & & \\
$\begin{array}{l}\text { Tomato } \\
\text { sauce }\end{array}$ & Penjar mean & $6.26 \mathrm{a}$ & $6.46 \mathrm{a}$ & $5.41 \mathrm{a}$ & $4.25 \mathrm{a}$ & $5.05 \mathrm{a}$ & $-0.12 \mathrm{a}$ \\
& Canary & $4.84 \mathrm{~b}$ & $5.63 \mathrm{~b}$ & $8.39 \mathrm{~b}$ & $2.29 \mathrm{a}$ & $5.63 \mathrm{a}$ & $-0.57 \mathrm{~b}$ \\
$\begin{array}{l}\text { Tomato } \\
\text { jam }\end{array}$ & Penjar mean & $6.14 \mathrm{a}$ & $6.22 \mathrm{a}$ & $2.53 \mathrm{a}$ & $7.26 \mathrm{a}$ & $3.50 \mathrm{a}$ & $0.48 \mathrm{a}$ \\
\hline
\end{tabular}



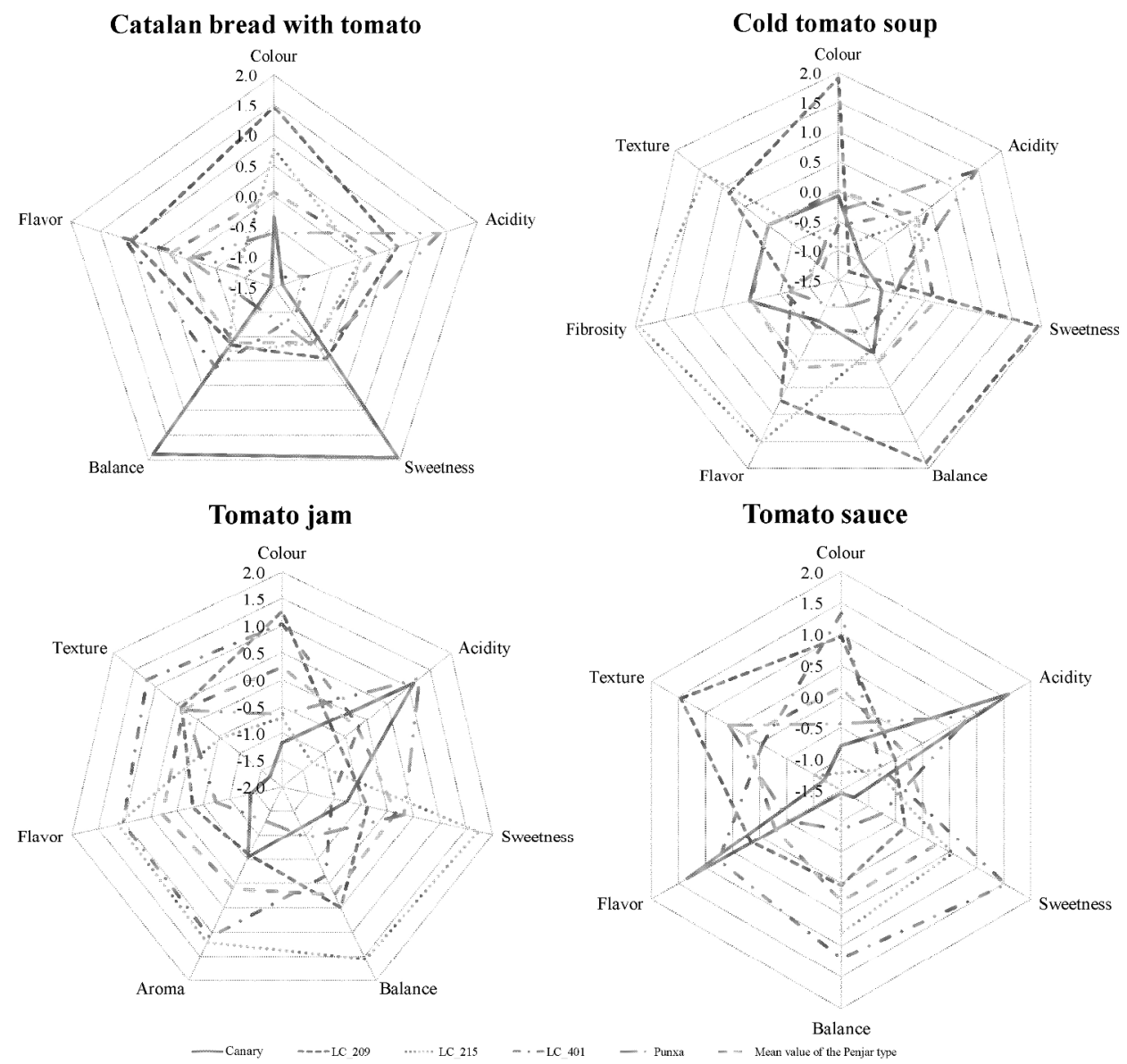

Figure 1 $846 \times 793 \mathrm{~mm}(96 \times 96$ DPI $)$ 
Figure 1. Radar charts for all the preparations, with the standardized data, and in each preparation the five varieties plus another entry representing the mean of the four "Penjar" varieties.

1

2

3

4

5

6

10

11

12

13

14

15

16

17

18

19

20

21

22

23

24

25

26

27

28

29

30

31

32

33

34

35

36

37

38

39

40

41

42

43

44

45

46

47

48

49

50

51

52

53

54

55

56

57

58

59

60 